\title{
HUOMIOITA MIKKO J. VIRTASEN KIRJOITUKSESTA "MONIÄÄNISYYDEN JA TAHDIKKUUDEN VÄLISSÄ. EETTISYYS ETENEN NEUVOTTELUKUNTATYÖSSÄ"
}

Tiede \& edistys julkaisi numerossaan 4/2018 (s. 306-325) Mikko J. Virtasen vertaisarvioiduksi merkityn artikkelin "Moniäänisyyden ja tahdikkuuden välissä: Eettisyys ETENEn neuvottelukuntatyössä." On hienoa, että eettisten neuvottelukuntien toimintaa arvioidaan tutkimuksessa ja eettisyyden toteutumista analysoidaan tiedelehdessä. Virtasen artikkelissa on kuitenkin sekä lähtökohtaa että aineistoa koskevia puutteita, jotka saavat kysymään, ovatko artikkelissa käytetyt taustatiedot riittävät ja kuinka vankkaan evidenssiin artikkelin johtopäätökset perustuvat.

Kirjoittaja tarkastelee ETENEn toimintaa toisaalta liittämällä sen osaksi lääketieteen eettisiä kysymyksiä käsittelevien neuvottelukuntien perustamista kansainvälisenä ilmiönä toisaalta osana suomalaista kontekstia. Tarkastelua olisi ollut syytä tarkentaa erottelemalla erityyppiset eettiset kysymykset toisistaan. Kiinnittämällä huomiota siihen, että lääketieteellinen tutkimus voi olla monella eri tavalla epäeettistä, kirjoittaja olisi voinut tehdä eron tutkimuskohteiden kohteluun liittyvien ja tutkimuksen tieteellisiä kriteerejä koskevien eettisten vaatimusten välillä. Kuvaamalla, kuinka lääketieteen eettisten kysymysten tarkastelu on vuosikymmenten kuluessa laajentunut hoidon ja terveydenhuollon etiikaksi ja bioetiikaksi, hän olisi voinut tuoda esiin sen, että lääketieteen etiikan tarkastelu irrotettuna sosiaalista hyvinvointia koskevasta eettisestä keskustelusta jää puutteelliseksi.
Artikkelissa kuvataan vain niukasti ETENEn perustamista, eikä sitä liitetä lainkaan suomalaisesta eettisten neuvottelukuntien järjestelmän kehittämiseen. Näin lukijalle ei selviä, millä tavoin vastuu eettisten kysymysten käsittelemisestä on jaettu Suomessa.

Kansallisia bioeettisiä neuvottelukuntia toimii nykyään yli 160 maassa. Useimmiten neuvottelukunta on rakentunut niin, että lääketieteellisten julkaisujen edellyttämän eettisen ennakkoarviointielimen toimivaltaa on laajennettu tai sen rinnalle on perustettu hoidon etiikkaa pohtiva elin. Monissa maissa neuvottelukunnalla on kiinteä yhteys poliittiseen päätöksentekoon esimerkiksi niin, että vallassa olevan hallituksen terveysasioista vastaava ministeri on neuvottelukunnan puheenjohtaja tai että asiantuntijajäsenillä ei ole äänioikeutta, kun toimielin päättää linjanvedoista, vaan poliittisin perustein valitut jäsenet tekevät ratkaisut. Suomalaisen mallin lähtökohtana on ajatus, että eettiset kysymykset ovat monimuotoisia, niitä on myös lääketieteen ulkopuolella, eivätkä ne kaikki koske tutkimusta.

Myös Suomessa lääketieteellisten tutkimuseettisten kysymysten ratkaiseminen linkittyi aluksi ETENEn toimintaan, kun tätä varten perustettu toimikunta, Tukija, toimi ETENEn jaoksena 30.9.2010 asti, minkä jälkeen se on ollut itsenäinen arviointielin. Tutkimuksen etiikan yleiset kysymykset ovat Tutkimuseettisen neuvottelukunnan (TENK) alaa. Biotekniikan neuvottelukunta ja Geeni- 
tekniikan lautakunta tekevät myös lainsäädännön valtuuttamia päätöksiä. Yhdessä Tiedonjulkistamisen neuvottelukunnan kanssa kaikki mainitut organisaatiot muodostavat eettisten neuvottelukuntien yhteistyöelimen.

Kokonaiskuvaa vääristävänä puutteena voidaan pitää myös sitä, että artikkelissa ETENEstä puhutaan vain lääketieteen etiikkaa tarkastelevana elimenä ja sivuutetaan - pelkällä asetuksesta poimitulla lainauksella - se, että ETENEn tehtäviä laajennettiin sen kolmannen toimikauden aikana 1.9.2009 käsittämään myös sosiaalialan eettiset kysymykset. Asetukseen sisältyvä ETENEn tehtävänanto korostaa, että terveys on vain osa ihmisen hyvinvointiin vaikuttavia tekijöitä, ja sen tarkasteleminen ihmisen sosiaalisista elinehdoista irrallaan on keinotekoista.

Artikkelista käy ilmi, että ETENE pitää kokouksia ja julkaisee kannanottoja. Varsinaisen analyysin taustaksi olisi kannattanut luonnostella monipuolisempi kuva neuvottelukunnan toiminnasta ja kertoa työmuodoista ja toiminnasta laajemmin.

Tutkimuksen toteutusta käsittelevässä kappaleessa (T\&E 4/2018, 310) kirjoittaja ilmoittaa toteuttaneensa tutkimuksen vuosina 2008-2018. Tekstistä ja kirjallisuusluettelosta käy ilmi, että tekijä on käynyt läpi kolme ETENEn nelivuotisten toimikausien lopuksi laatimaa kausijulkaisua vuosilta 1998-2010. Artikkelissa mainittu tutkimuksen aikarajaus ei näin vastaa käytettyä kirjallista aineistoa.

Toinen aineisto koostuu kahden ETENEn kokouksen havainnoinnista ja ETENEn jäsenille suunnatusta kyselystä. Virtanen on osallistunut kahteen ETENEn kokoukseen useita vuosia sitten, missä yhteydessä hän on myös pyytänyt ETENEn jäseniä vastaamaan työskentelyä koskeviin kysymyksiin. Artikkelissa ilmoitettu tutkimuksen aikarajaus on virheellinen myös empiirisen aineiston kannalta.

Tutkimuksen toteuttamisen ja tutkimusraportin julkaisemisen välillä voi eri syistä kulua aikaa. Hyvään tieteelliseen käytäntöön kuuluu kuitenkin myös sen raportoiminen, miltä ajanjaksolta aineisto on peräisin. Nyt artikkelissa määritelty aikarajaus on virheellinen sekä suhteessa kirjoittajan käyttämään kirjalliseen että tutkimuksen pohjana olevaan empiiriseen aineistoon.

ETENEen kuuluu puheenjohtajan ja varapuheen johtajan lisäksi 18 neljän vuoden toimikaudeksi valittua jäsentä ja heidän henkilökohtaiset varajäsenensä, joilla on oikeus osallistua aina kokouksiin riippumatta siitä, tuleeko varsinainen jäsen kokoukseen vai ei. Lisäksi neuvottelukunnalla on päätoiminen pääsihteeri. Näin ETENEn toimintaan osallistuu kerrallaan noin 40 ihmistä, joista useimmat aktiivisesti. Virtasen olisi ollut syytä suhteuttaa kyselyynsä saamat seitsemän vastausta ETENEn jäsenmäärään.

ETENEssä neljättä kautta erilaisissa rooleissa toimineena voin tunnistaa Virtasen analyysista ETENEn toimintaa luonnehtivia elementtejä. Puutteet, jotka olen tuonut esiin, heikentävät kuitenkin artikkelin luotettavuutta tutkimuksena.

- JAANA HALLAMAA

Sosiaalietiikan professori, ETENEn varajäsen 2002-2006, varapuheenjohtaja 2006-2010, puheenjohtaja 2014-2018 ja 2018-2022. 